\title{
THE INFLUENCE OF CORN OIL SUPPLEMENTS ON FATTY ACID PATTERNS IN ISCHÆMIC HEART DISEASE
}

\author{
BY \\ T. D. V. LAWRIE, S. G. MCALPINE, B. M. RIFKIND, AND J. ROBINSON \\ From the Cardiology Department, Royal Infirmary, Glasgow
}

Received August 7, 1961

Since Groen et al. (1952) reported on the ability of various dietary fats to influence serum cholesterol levels, many workers have shown that'diets rich in unsaturated fatty acids can lower the cholesterol and triglyceride levels of the plasma or serum (Kinsell et al., 1952; Malmros and Wigand, 1957; Keys et al., 1957; Ahrens et al., 1959; Antonis and Bersohn, 1961), but there have been comparatively few reports on the effects of various dietary fatty acids on the fatty acid patterns of the plasma or serum lipids based on the study of adequate numbers of patients over sufficiently long periods. The present study was undertaken to determine the effect on the fatty acid patterns of the cholesterol ester, triglyceride, and phospholipid fractions of serum, of a diet rich in unsaturated fatty acids taken for more than a year.

\section{SUBJECTS AND METHODS}

Thirteen male patients were studied. Their ages ranged from 43 to 64 years (mean age 54 years). All had had a myocardial infarction more than four weeks, but less than four months, before commencing their special diet. None were on anticoagulant therapy. They had been taking a corn oil supplemented diet for at least 16 months and not more than 22 months. This diet provided 16002200 calories a day, was low in animal fat, and contained $50 \mathrm{~g}$. of corn oil. The total daily fat intake was about $80 \mathrm{~g}$. Estimations had been made of their serum cholesterol before therapy commenced and at the time of the fatty acid analysis. The mean pre-treatment figure was $290 \mathrm{mg} . / 100$ $\mathrm{ml}$. (range $229-373 \mathrm{mg} . / 100 \mathrm{ml}$.) and the mean figure at the time of sampling was $241 \mathrm{mg} . / 100 \mathrm{ml}$. (range 187-314 mg./100 ml.). A more detailed report of the effect of the corn oil on the serum cholesterol levels will be given elsewhere.

The methods used for analysis were those employed in our previous studies and have been described in detail (Lawrie et al., 1961b). After an overnight fast $20 \mathrm{ml}$. samples of blood were taken from each patient and allowed to clot. Lipid was extracted from the serum and the acetone-soluble fraction (containing cholesterol ester and triglyceride) derived from it was applied to a silicic acid column, and the cholesterol esters separated from the triglycerides by a modification of the method of Hirsch and Ahrens (1958). The acetone-insoluble fraction of the serum lipid contained phospholipid. The fatty acids were obtained from each of the fractions, methylated with diazomethane, and submitted to gas-liquid chromatography using a Pye Argon Gas Chromatograph. The stationary phase employed was polyethylene glycol adipate at a temperature of $174^{\circ} \mathrm{C}$. The acids of chain length from $C_{12}$ through $C_{20}$ were analysed.

Acids were identified mainly by using the relative retention volume data of Farquhar et al. (1959) and by comparing the time of emergence of unknown acids with those of known acids run under similar chromatographic conditions. Details regarding specific identification of the serum fatty acids have been discussed elsewhere (Lawrie et al., 1961b). 
The nomenclature used to simplify description of the many fatty acids encountered is that introduced by Ahrens et al. (1959). A dual symbol is used, the first figure referring to chain length and the second to the number of double bonds present.

\section{RESULTS}

The fatty acid composition of the corn oil supplement was defined by gas-liquid chromatography (Table). The figures are in agreement with those of Dole et al. (1959), Insull et al. (1959), and Ahrens et al. (1959) for the composition of corn oil, especially with regard to its linoleic acid content.

TABLE

Fatty Acid Composition of Lipid Fractions of Patients Receiving Either an Ordinary or a CoRn Oil SuppleMENTED DIET, AND OF CORN OIL

\begin{tabular}{|c|c|c|c|c|c|c|c|}
\hline \multirow[b]{2}{*}{$\begin{array}{l}\text { Fatty } \\
\text { acid }\end{array}$} & \multirow[b]{2}{*}{$\begin{array}{c}\text { Corn } \\
\text { oil }\end{array}$} & \multicolumn{2}{|c|}{ Cholesterol esters } & \multicolumn{2}{|c|}{ Triglycerides } & \multicolumn{2}{|c|}{ Phospholipids } \\
\hline & & $\begin{array}{l}\text { Ordinary } \\
\text { diet } \\
(17)\end{array}$ & $\begin{array}{c}\text { Corn oil } \\
\text { supplement } \\
\text { (13) }\end{array}$ & $\begin{array}{l}\text { Ordinary } \\
\text { diet } \\
\text { (13) }\end{array}$ & $\begin{array}{c}\text { Corn oil } \\
\text { supplement } \\
\text { (11) }\end{array}$ & $\begin{array}{l}\text { Ordinary } \\
\text { diet } \\
(14)\end{array}$ & $\begin{array}{c}\text { Corn oil } \\
\text { supplement } \\
\text { (10) }\end{array}$ \\
\hline $\begin{array}{l}14: 0 \\
14: 1 \\
16: 0 \\
16: 1 \\
18: 0 \\
18: 1 \\
18: 2 \\
20: 3 \\
20: 4\end{array}$ & $\begin{array}{r}10.4 \\
1.4 \\
29.5 \\
53.5\end{array}$ & $\begin{array}{c}1 \cdot 7 \pm 1 \cdot 0 \\
0 \cdot 8 \pm 0 \cdot 7 \\
14 \cdot 9 \pm 4 \cdot 2 \\
5 \cdot 7 \pm 2 \cdot 1 \\
2 \cdot 9 \pm 1 \cdot 5 \\
19 \cdot 9 \pm 4 \cdot 9 \\
30 \cdot 3 \pm 10 \cdot 8 \\
1.4 \pm 1 \cdot 7 \\
6 \cdot 4 \pm 6 \cdot 0\end{array}$ & $\begin{array}{r}1 \cdot 8 \pm 1 \cdot 4 \\
0 \cdot 7 \pm 0 \cdot 7 \\
13 \cdot 0 \pm 2 \cdot 0 \\
4 \cdot 6 \pm 1 \cdot 5 \\
3 \cdot 0 \pm 1 \cdot 1 \\
17 \cdot 4 \pm 4 \cdot 3 \\
42 \cdot 9 \pm 4 \cdot 8 \\
0.7 \pm 0 \cdot 4 \\
5 \cdot 1 \pm 1 \cdot 1\end{array}$ & $\begin{array}{r}3 \cdot 1 \pm 1 \cdot 6 \\
1 \cdot 9 \pm 1 \cdot 1 \\
20 \cdot 2 \pm 6 \cdot 0 \\
7 \cdot 5 \pm 3 \cdot 2 \\
4 \cdot 3 \pm 1 \cdot 6 \\
26 \cdot 4 \pm 9 \cdot 9 \\
10 \cdot 3 \pm 3 \cdot 3 \\
2 \cdot 1 \pm 3 \cdot 2 \\
3 \cdot 6 \pm 6 \cdot 1\end{array}$ & $\begin{array}{r}2 \cdot 7 \pm 1 \cdot 3 \\
1 \cdot 2 \pm 0 \cdot 8 \\
21 \cdot 5 \pm 4 \cdot 7 \\
5 \cdot 8 \pm 2 \cdot 1 \\
5 \cdot 8 \pm 2 \cdot 9 \\
26 \cdot 0 \pm 5 \cdot 4 \\
19 \cdot 2 \pm 6 \cdot 8 \\
1 \cdot 3 \pm 1 \cdot 4 \\
2 \cdot 1 \pm 0 \cdot 7\end{array}$ & $\begin{array}{r}1 \cdot 1 \pm 0 \cdot 4 \\
0 \cdot 4 \pm 0 \cdot 3 \\
25 \cdot 1 \pm 5 \cdot 2 \\
4 \cdot 1 \pm 1 \cdot 9 \\
11 \cdot 3 \pm 3 \cdot 1 \\
17 \cdot 9 \pm 4 \cdot 1 \\
19 \cdot 6 \pm 5 \cdot 0 \\
2 \cdot 2 \pm 1 \cdot 4 \\
7 \cdot 4 \pm 2 \cdot 3\end{array}$ & $\begin{array}{r}1 \cdot 9 \pm 0 \cdot 9 \\
1 \cdot 1 \pm 0 \cdot 8 \\
26 \cdot 0 \pm 4 \cdot 8 \\
3 \cdot 0 \pm 1 \cdot 4 \\
10 \cdot 7 \pm 2 \cdot 8 \\
12 \cdot 9 \pm 3 \cdot 3 \\
20 \cdot 7 \pm 4 \cdot 0 \\
2 \cdot 5 \pm 1 \cdot 4 \\
7 \cdot 7 \pm 2 \cdot 3\end{array}$ \\
\hline
\end{tabular}

Mean value and standard deviations expressed as a percentage by weight of the total fatty acids in each fraction.

The figure below the description of the diet refers to the number of samples analysed.

The results of the analyses of the fatty acid patterns of the cholesterol esters, triglycerides, and phospholipids from the serum of patients receiving a corn oil supplemented diet are set out in the Table together with the results from our previous study of the corresponding fatty acid patterns from 18 patients with ischæmic heart disease on an ad libitum diet (Lawrie et al., 1961a). The latter group comprised 16 male and 2 female patients with a mean age of 58 years (range 47 to 77 years). Each acid is expressed as a percentage by weight of the total fatty acids within a fraction and only the major fatty acid components are tabulated.

Statistical analyses of the results, using the "t-test," showed the linoleic acid percentage content of the cholesterol esters and triglycerides from the patients receiving corn oil to be significantly higher than the content of this acid in the corresponding fractions obtained from the patients on an ordinary diet (cholesterol esters: $t=3.93, p<0.001$; triglycerides: $t=4.36, p<0.001$ ). In the phospholipid fraction no significant rise in linoleic acid was found in the patients receiving the corn oil supplement, but the percentage of oleic acid was significantly less than in the patients on ordinary $\operatorname{diet}(\mathrm{t}=3 \cdot 30, \mathrm{p}<0 \cdot 01)$.

\section{DisCussion}

Previous work on the influence of dietary fatty acids on serum fatty acids has been largely limited to the study of hypercholesterolæmic subjects or to observations on small numbers of subjects or to single serum lipid fractions. Thus Dole et al. (1959) found relatively little alteration in the fatty acid composition of various plasma lipid fractions over a period of several hours after the ingestion of corn oil, coconut oil, or butter. Ahrens et al. (1959) showed that changes in the fatty acid patterns of the cholesterol esters and triglycerides of serum could be produced by manipulation of the fatty acid composition of the diet over a period of several weeks, though the phospholipid fraction was relatively resistant to change; but this study was carried out on only two patients both of whom 
suffered from idiopathic hypercholesterolæmia, so it might be unwise to generalize from their findings. Likewise the three patients studied by Bjorntorp and Hood (1960) were cases of idiopathic hypercholesterolæmia. Insull et al. (1959) in a study of the serum of a lactating mother fed various types of fats, showed that her dietary fatty acid pattern was most closely simulated by the pattern of the triglyceride fatty acids: the cholesterol esters also showed considerable avidity for the linoleic acid of corn oil. Her phospholipids were found to be the fraction least sensitive to shifts in dietary fatty acids. It has been demonstrated in the South African White and Bantu that the pattern of dietary fat is reflected in the blood triglyceride fraction (Antonis and Bersohn, 1961), and Hallgren et al. (1960) have found, in a single subject, an indication of his dietary fatty acids in his plasma fatty acids patterns, especially in the cholesterol esters and triglycerides.

The present study confirms and extends these observations. It shows that, in a group of patients with coronary artery disease and without a marked increase in the serum cholesterol, both the cholesterol esters and triglycerides of the serum reflected the high content of linoleic acid in the dietary supplement, and it may be that unsaturated fatty acids reduce serum cholesterol and triglyceride by increasing the degree of unsaturation of cholesterol and triglyceride fatty acids. There was no increase in the percentage of arachidonic acid or of the 20:3 acid in the two fractions although these acids have been shown, in the rat, to be derived from linoleic acid (Mead and Howton, 1957; Howton and Mead, 1960): furthermore an absolute increase in the amounts of each of these acids is unlikely to have occurred since corn oil feeding depresses the level of serum cholesterol and triglyceride.

The serum phospholipid fraction showed a small and statistically insignificant rise in linoleic acid following corn oil feeding. This is in keeping with the findings of Ahrens et al. (1959), Insull et al. (1959), and Hallgren et al. (1960) that the phospholipids of serum or plasma appear to be the more stable fraction in the face of alteration of the dietary fatty acids. It is interesting to note that the red blood cell appears to differ somewhat from its surrounding medium in that the red cell phospholipids can be strongly influenced by corn oil feeding (Liebetseder and Ahrens, 1959).

It is difficult to explain our observation that the phospholipid oleic acid appeared to fall on corn oil feeding. It is possible that the substitution of corn oil with its relatively low content of oleic acid $(29.5 \%)$ resulted in the oleic acid percentage of the total dietary fatty acids being reduced. Figures for the oleic acid content of the average British diet are difficult to come by, though oleic acid has been said to be the most common unsaturated fatty acid in the human diet (Riley and Nunn, 1960), and tentative figures suggest that, in 1957, mono-unsaturated acids constituted about 42 per cent of the fatty acid composition of food consumed in the United Kingdom (B. J. F. Hudson, personal communication). If a reduction in the oleic acid percentage of the diet is indeed responsible for the fall in oleic acid of the phospholipids, it is difficult to understand why this has not been reflected in the other two lipid groups which appear to be more sensitive to alterations in the dietary fatty acids. Possibly some partitioning of dietary fatty acids occurs with oleic acid being taken preferentially into the phospholipids and linoleic acid into the cholesterol esters and triglycerides.

The present study also shows that the fatty acid patterns of the lipid fractions of serum may be influenced by the fatty acid constitution of the diet. Consequently it is possible that the serum fatty acid patterns of any subject reflect, to a certain extent, the pattern of his dietary fatty acids. Studies of serum fatty acid patterns, particularly of the triglyceride fraction, of comparable subjects from different populations might prove to be a useful guide to the fatty acid patterns of the diet of such groups, perhaps indicating whether any populations are relatively deficient in the so-called essential or unsaturated fatty acids. The figures of James et al. (1957) for the fatty acid patterns of the acetone-soluble fractions of serum (cholesterol esters and triglycerides) of British subjects when compared with the corresponding figures of Dole et al. (1959) for American subjects suggest that differences do exist between the fatty acid patterns of the blood from different populations.

\section{SUMMARY}

The fatty acid patterns of the cholesterol ester, triglyceride, and phospholipid fractions of the serum from 13 patients receiving a corn oil supplement to their diet for more than a year have been 
compared with the corresponding fatty acid patterns of a group of patients on an libitum diet. A reflection of the high linoleic acid content of the dietary supplement was found in the cholesterol ester and triglyceride fractions but not in the phospholipids, the main change in which was a significant fall in the percentage of oleic acid.

We wish to thank Dr. J. H. Wright for helpful criticism and Dr. J. Eaton for laboratory facilities. We are grateful to Dr. R. A. Robb of the Mathematics Department, Glasgow University, for statistical advice, and to Unilever Ltd., Port Sunlight, for provision of samples of fatty acids. We are indebted to Professor L. J. Davis and Dr. W. C. Watson for allowing us to study their patients and for providing the cholesterol results.

This work was supported by a grant from the Scottish Hospital Endowment Research Trust.

\section{REFERENCES}

Ahrens, E. H., Jr., Hirsch, J., Insull, W., Jr., Peterson, M. L., Stoffel, W., Farquhar, J. W., Miller, T., and Thomasson, H. J. (1959). Lancet, 1, 115.

Antonis, A., and Bersohn, I. (1961). Lancet, 1, 3.

Bjorntorp, P., and Hood, B. (1960). Circulat. Res., 8, 319.

Dole, V. P., James, A. T., Webb, J. P. W., Rizack, M. A., and Sturman, M. F. (1959). J. clin. Invest., $38,1544$.

Farquhar, J. W., Insull, W., Jr., Rosen, F., Stoffel, W., and Ahrens, E. H., Jr. (1959). Nutr. Rev., $17,1$.

Groen, J., Tjiong, B. G., Kaminga, C. E., and Willebrand, A. F. (1952). Voeding, 13, 556.

Hallgren, B., Stenhagen, S., Svanborg, A., and Svennerholm, L. (1960). J. clin. Invest., 39, 1424.

Hirsch, J., and Ahrens, E. H., Jr. (1958). J. biol. Chem., 233, 311.

Howton, D. R., and Mead, J. F. (1960). J. biol. Chem., 235, 3385.

Insull, W., Jr., Hirsch, J., James, T., and Ahrens, E. H., (1959). J. clin. Invest., 38, 443.

James, A. T., Lovelock, J. E., Webb, J., and Trotter, W. R. (1957). Lancet, 1, 705.

Keys, A., Anderson, J. T., and Grande, F. (1957). Lancet, 1, 787.

Kinsell, L. W., Partridge, J., Boling, L., Margen, S., and Michaels, G. (1952). J. clin. Endocr., $12,909$.

Lawrie, T. D. V., McAlpine, S. G., Rifkind, B. M., and Robinson, J. F. (1961a). Lancet, 1, 421.

,- , Pirrie, R., and Rifkind, B. M. (1961b). Clin. Sci., 20, 255.

Liebetseder, F., and Ahrens, E. H. (1959). Brit. J. Hamat., 5, 356.

Malmros, H., and Wigand, G. (1957). Lancet, $2,1$.

Mead, J. F., and Howton, D. R. (1957). J. biol., Chem., 229, 575.

Riley, C., and Nunn, R. F. (1960). Biochem. J., 74, 56. 